\title{
Assessment of soil characteristics in orchard
}

\author{
Nagy, A. ${ }^{1}$, Fórián, T. ${ }^{1}$, Tamás, J. ${ }^{1}$, Szabó, Z. $^{2}$, Nyéki, J. ${ }^{2}$ \& Soltész, M. ${ }^{3}$ \\ ${ }^{1}$ University of Debrecen, Centre of Agricultural Sciences and Engineering, Faculty of Agricultural and Food \\ Sciences and Environmental Management, Institute of Water and Environmental Management, \\ H-4032 Debrecen, Böszörményi str. 138, Hungary, attilanagy@agr.unideb.hu \\ ${ }^{2}$ University of Debrecen, Institute for Research and Development, \\ H-4032 Debrecen, Böszörményi str. 138, Hungary \\ ${ }^{3}$ Collage of Kecskemét, Faculty of Horticulture, H-6000 Erdei Ferenc tér 1-3.
}

\begin{abstract}
Summary: The research field was at Siófok, in Hungary, which is situated in the South East side of Lake Balaton. The physical characteristic of the soil is sandy loam and loam and the peach orchard is irrigated. The detailed goals were mapping and analyzing of physical properties of the soil in water management point of view, mapping the acidity and $\mathrm{CaCO}_{3}$ content of soil for precision liming, measurement of humus the element content. Sites with different physical characteristics (from sandy loam to loamy clay) could be distinguished. The reason for this is that besides the possible increase of clayminerals, the increasing rate of colloidal humus content contributes to larger soil plasticity. Statistics also proved positive and strong correlation $(\mathrm{r}=0.822)$ between the soil plasticity and humus content. In the case of $\mathrm{pH}$, only a small part of the orchard is has to be limed, since most of the orchard has neutral $\mathrm{pH}$, which is advantageous for nuts and stone fruits. It has to be mentioned, that the $\mathrm{CaCO}_{3}$ supply is also appropriate for the stone fruits. Based on the results hyperspectral imagery can be a good solution for detecting calciferous soils, although these measurements are still need validation.
\end{abstract}

Key words: hyperspectral imaging, precision agriculture, $\mathrm{CaCO}_{3}$ content

\section{Introduction}

Spatial variability of soil properties may appear in yield variation within a single field even in areas considered to be homogeneous from soil survey point of view. Effects of various sources of soil heterogeneity on the annual or longterm average soil water budget appear to differ markedly (Kim, 1995). Furthermore the negative water balance in the Carpathian Lowland: $450-600 \mathrm{~mm}$ precipitation vs. $680-720 \mathrm{~mm}$ potential evapotranspiration is equilibrated by horizontal inflow (on the surface as runoff, in the unsaturated zone as seepage; and in the saturated zone as groundwater flow), which leads to the accumulation of the weathering products of the large catchment area. In addiction to the hardly predictable atmospheric precipitation pattern, the two additional reasons of extreme soil moisture regime (the simultaneous hazard of waterlogging or overmoistening and drought sensitivity) are:

- the heterogeneous microrelief of the „flat” lowland;

- the highly variable, sometimes mosaic-like soil cover and the unfavourable physical and hydrophysical properties of some soils (mainly due to heavy texture, high clay and swelling clay content, or high sodium saturation: ESP).

The hyper- and multispectral technology is widely used in the precision agriculture (Burai, 2006; Milics et al. 2008), field growing of plants, and nowadays in gardening culture (Tamás et al. 2009). Remote sensing technologies make a possibility to the time series analyzing of the gardening stock and obtaining information of qualitative and quantitative parameters of plants (Berke et al. 2004).

\section{Materials and methods}

The main goal is to establish such a precision decision support system, with which the water management properties of soil can be meliorated, and can be reduced the effect of high precipitation intensity on orchards.

The research field was at Siófok, in Hungary, which is situated in the South East side of Lake Balaton. Upper limit of soil plasticity according to Arany, soil density, acidity, $\mathrm{CaCO}_{3}$, humus, $\mathrm{N}$ and $\mathrm{P}$ content, main microelements of soils were measured to obtain appropriate information on the physical and water management properties of the soil. The detailed goals were the followings:

- mapping and analyzing of physical properties of the soil in water management point of view,

- mapping the acidity and $\mathrm{CaCO}_{3}$ content of soil for precision liming,

- measurement of humus the element content.

Due to the heterogeneous terrain surface special attention has to be paid to places with different location in order to examine all of the different soil varieties. The coordinates of the sampling points were collected by GPS (Figure 1.). Systematic sampling strategy was carried out based on the 
number of the rows and apple trees to collect as much information as possible with possibly the least number of samples. Geoinformatics calculations were made in ArcGIS 10 environment.

Beside soil sampling and measurement, hyperspectral imaging was also made on this site in order to examine certain soil propoperties. In 2006, an AISA DUAL airborne hyperspectral cam system were installed and operated in cooperation the University of Debrecen, AMTC, Department of Water and Environmental Management with the Mechanization Institute of Agricultural Ministry in Gödöllő. The most important parts of the hyperspectral sensors are the spectrograph, which dissolve the electric waves arrived through the optical rift with the help of prisms and optical screen. The hyperspectral sensor consists of one optic, one spectrograph and one digital cam. The two hyperspectral sensors are assembling in a house; therefore it is known ASIA DUAL system. The two cameras can perceive in the visible wavelength, near infrared range and short wave infrared range.

Technical information of ASIA

DUAL hyperspectral system (Table 1.):

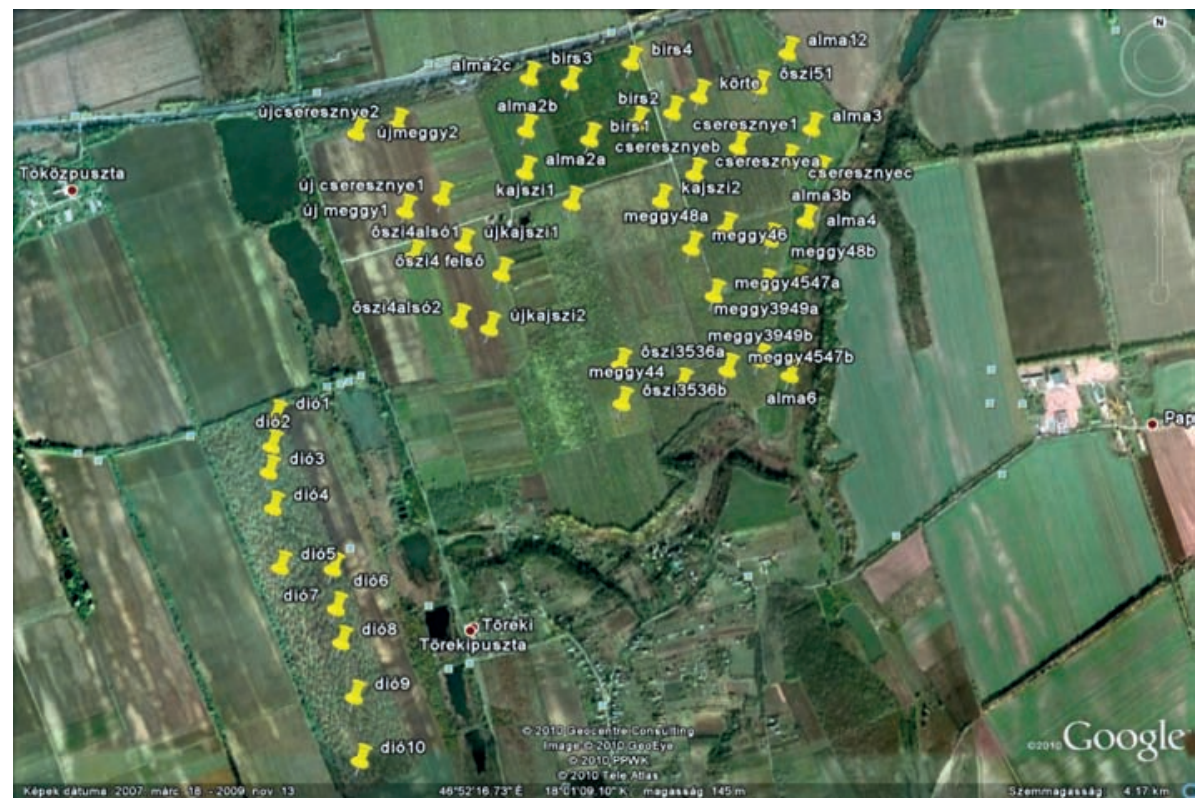

Figure 1. Soil sampling points at the orchard

Table 1. Technical information of ASIA DUAL hyperspectral system

\begin{tabular}{|l|c|c|c|}
\hline & VNIR sensor (Eagle) & SWIR sensor (Hawk) & AISA Dual \\
\hline Spectral range & $400-970 \mathrm{~nm}$ & $970-2450 \mathrm{~nm}$ & $400-2450 \mathrm{~nm}$ \\
\hline Spectral resolution & 244 & 254 & 498 \\
\hline Spectral sampling/px & $2.3 \mathrm{~nm}$ & $5.8 \mathrm{~nm}$ & \\
\hline Spectral binning options & 12 & 14 & 14 \\
\hline Spatial pixels & 1024 & 320 & 320 \\
\hline Fore optics & $18.04 \mathrm{~mm}$ & $18.04 \mathrm{~mm}$ & \\
\hline FOV & 37.7 degrees & 24 degrees & 24 degrees \\
\hline IFOV & 0.037 degrees & 0.075 degrees & 0.075 degrees \\
\hline Image rate & Up to $100 \mathrm{img} / \mathrm{s}$ & Up to $100 \mathrm{img} / \mathrm{s}$ & Up to $100 \mathrm{img} / \mathrm{s}$ \\
\hline
\end{tabular}

- Push-broom hyperspectral imagery sensor with the fibre optic radiation meters (FODIS)

- Miniature integrated GPS/INS sensor, which serves the position, height and momentary situation (pith, roll, yaw) of plane

- Compact PC-based data collector and mobile receiver unit

- CaliGeo software runs as a separate software package under the ENVI software package to do the spectral and geometrical corrections

- The parameters of the hyperspectral image:

- Wavelength: 400-2450 nm (EAGLE: 400-970 nm and HAWK: 970-2450 nm)

- Spectral sample taking: $1,2-10 \mathrm{~nm}$

- Ground resolution: 0,4-3 m (with plane)

The Eagle camera takes images in visible and near infrared range (VNIR), while Hawk operates in the middle infrared range (SWIR). By means of establishing of two camera a DUAL system were installed. The full range 400$2450 \mathrm{~nm}$, which can be set 1,25-10 nm wavelength band and maximum 498 spectral channels. Two sensors can also be

operated separately, so it makes possible to utilize the wider wavelength of higher resolution (1024 pixels) VNIR sensor.

The AISA DUAL sensor recorded spectra at SWIR I,II $(1,5-1,8 ; 2,0-2,5)$, which is suitable for the determination of minerals and quartz (Kardeván, 2003).

\section{Results and discussion}

Based on soil plasticity, according to Arany, sites with different physical characteristics (from sandy loam to loamy clay) could be distinguished. The spatial variability of soil plasticity, thus the physical features of the soil appeared differently (Figure 2.). Since the maximal saturation percentage $\left(\mathrm{K}_{\mathrm{A}}=48,05\right)$ measured at the sampling point with the highest altitude, it was possibly caused by erosion processes. Concerning the humus content, the same spatial distribution can be found as the soil plasticity. The reason for this is that besides the possible increase of clayminerals, the increasing rate of colloidal humus content contributes to larger soil plasticity. Statistics also proved positive and 
strong correlation $(\mathrm{r}=0.822)$ between the soil plasticity and humus content.

Although the spatial distribution of $\mathrm{pH}$ and calcium carbonate does not show strong correlation as it was supposed, the results can be used in precision agriculture. In the case of $\mathrm{pH}$, only a small part of the orchard is has to be limed, since most of the orchard has neutral $\mathrm{pH}$, which is advantageous for nuts and stone fruits. It has to be mentioned, that the $\mathrm{CaCO}_{3}$ supply is also appropriate for the stone fruits. The measured extremities are probably due to sampling errors.

An image extract was taken form the hyperspectral image containing the extended environment of the plantation. After the geometric and radiometric correction the hyperspectral $n$-dimensional data cube was made, which was then ready for classification. This data cube contains all geographical and spectral data changing pixel by pixel (Figure 4).

Spectral reflectance curve is typical for every object, but in mixed surface, the spectral data are also mixed. Before classifications, spectrally clean, not mixed pixels of the objects should be found. The spectral profile shows the spectral value regarding to 1 pixel $\left(1 \mathrm{~m}^{2}\right)$ in case of all channels. These are the spectrally not correlated pixels called endmembers that are spectrally matched to similar spectral curves in the spectral space. In Figure 3, right site presents two typical endmembers, one of them is a peach tree in $343 \mathrm{x}$, $4280 \mathrm{y}$; while, the left side shows a spare light clay soil in $172 \mathrm{x}, 4442 \mathrm{y}$ pixel position. The curves show relatively high differences in red channels around $650 \mathrm{~nm}$ and NIR channels close to $740 \mathrm{~nm}$, and this is why these ranges are intensively used for interpretations. In order to investigate the soil properties by hyperspectral imaging the canopy cover was masked. Masking was made based on the NDVI image of the orchard.

Spectra were collected at several representative point of sample area to analyze spectral curves regarding the $\mathrm{CaCO}_{3}$ content. Since based on soil measurements there is a calciferous soil at the examined orchard, the spectra from the
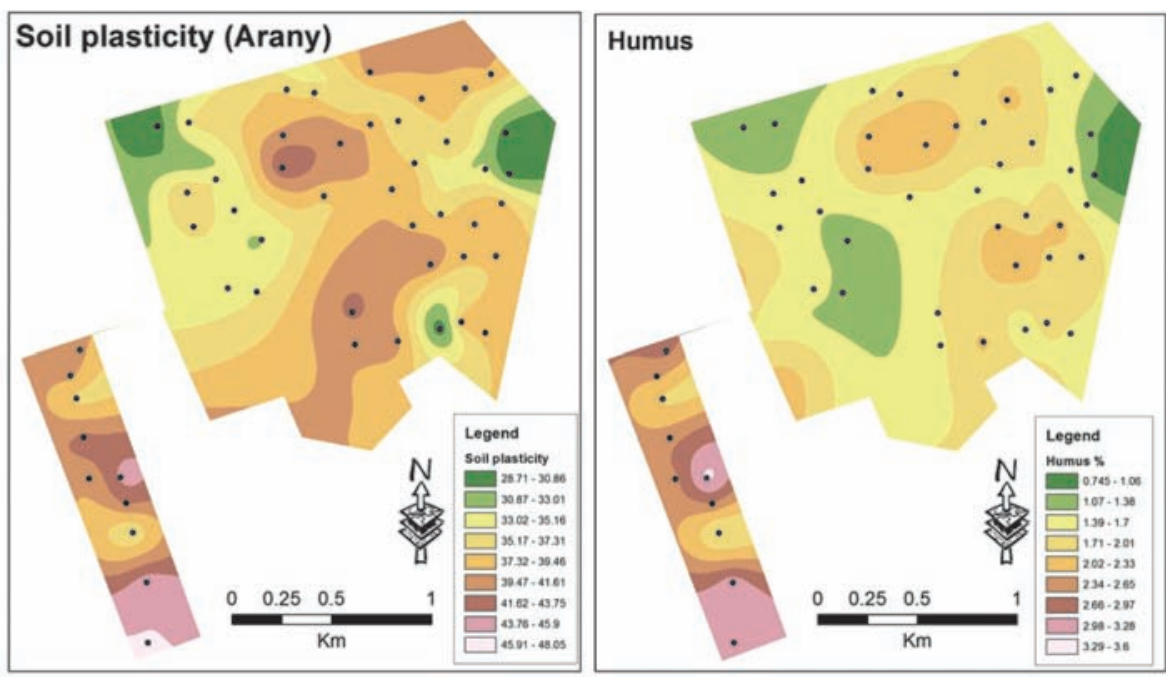

Figure 2. Spatial distribution of soil plasticity and humus
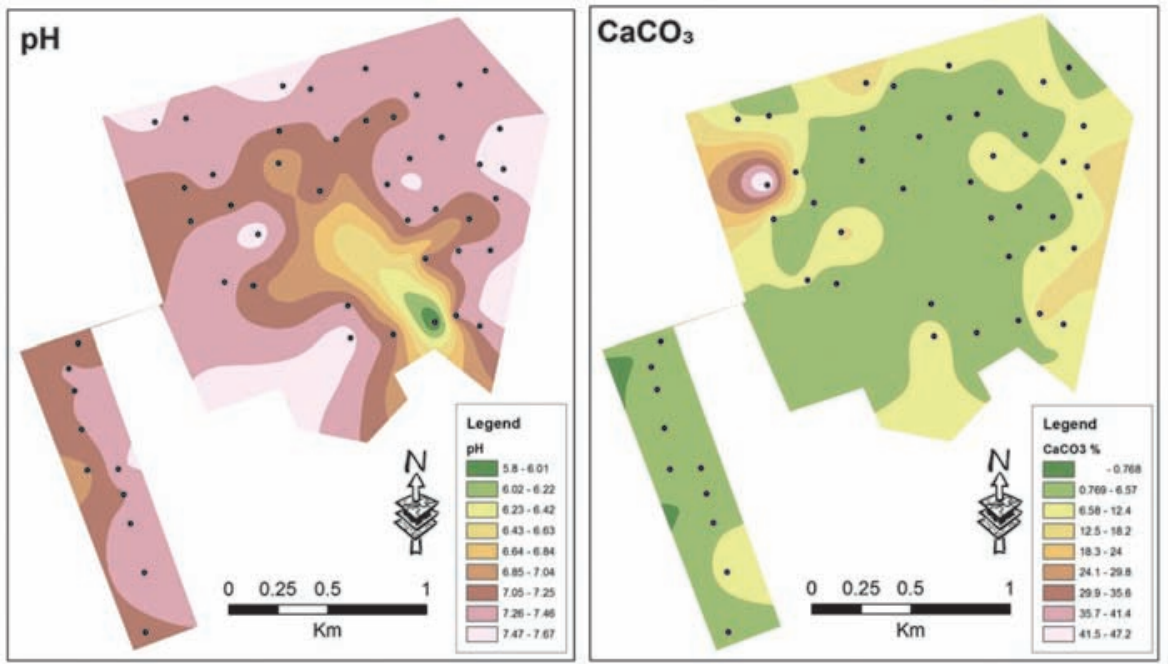

Figure 3. Spatial distribution of $\mathrm{pH}$ and $\mathrm{CaCO}_{3}$
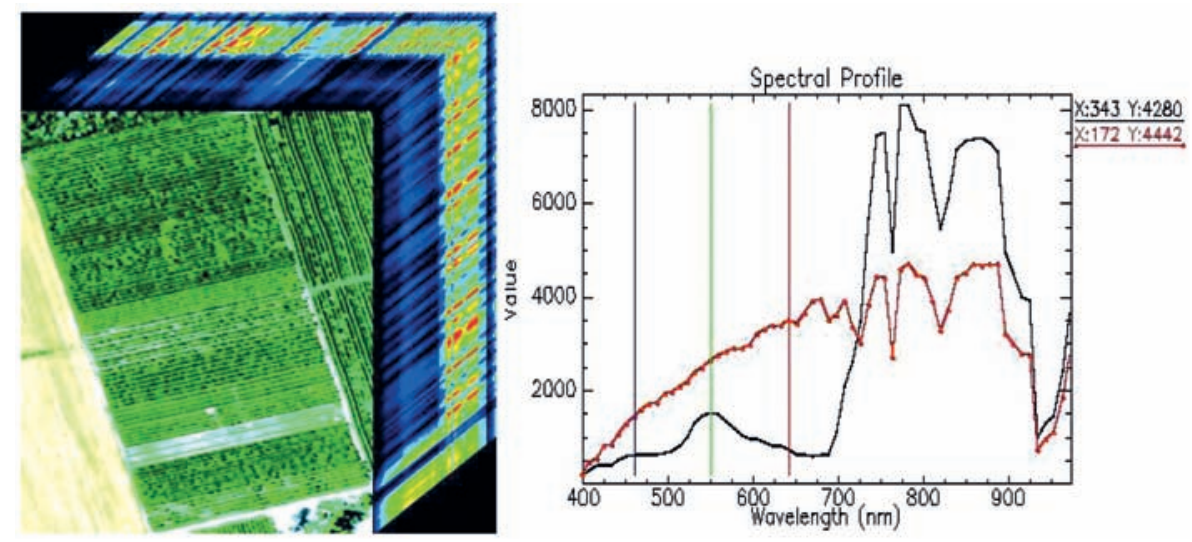

Figure 4. The 3D data cube made from 69 VIS-NIR channels and spectral reflectance curves of pixels 


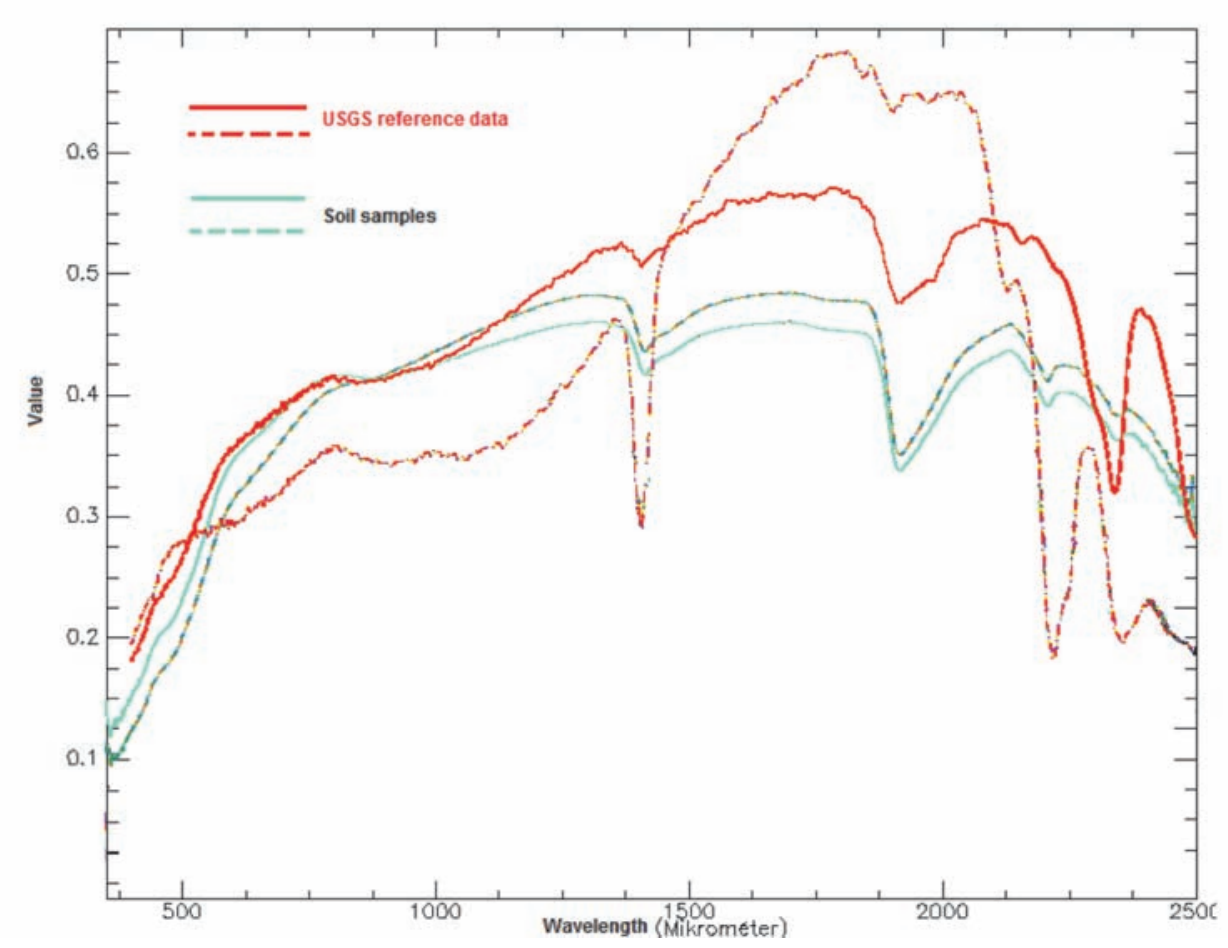

Figure 5. Spectral properties of the USGIS reference and soil sample data

from the hyperspectral image are very similar (Figure 5). Based on these results hyperspectral imagery can be a good solution for detecting calciferous soils, although these measurements are still need validation.

\section{Acknowledgement}

This study is funded by TECH_08-A3/2-2008-0373 and TECH_08-A4/2-2008-0138 projects.

\section{References}

Berke, J., Kelemen, D., Szabó, J. (2004): Digitális képfeldolgozás és alkalmazásai. PICTRON Kft., Keszthely

Burai P. (2006): Földhasználat-elemzés és növény-monitoring különböző adattartalmú és térbeli felbontású távérzékelt felvételek alapján. Agrártudományi Közlemények, 22: 7-12.
Kardeván P., Vekerdy Z., Róth L., Sommer ST., Kemper TH., Jordan GY., Tamás J., Pechmann I., Kovács E., Hargitai H., László F. (2003): Outline of scientific aims and data processing status of the first Hungarian hyperspectral data acquisition flight campaign, HYSENS 2002 HUNGARY. 3rd EARSEL Workshop on imaging spectroscopy, 324-332.

Kim R. (1995): The water budget of heterogeneous areas. Doctoral thesis. Wageningen Agricultural University. Wageningen

Milics, P., Burai, P., Lénárt , Cs. (2008): Pre-harvest prediction of spring barley nitrogen content using hyperspectral imaging. Cereal Research Communication. 36: 1863-1866.

Tamás, J., Lénárt, Cs., Burai, P. (2009): Evaluation of applicability of airborne AISA DUAL hyperspectral imaging system to map environment conditions in orchards. In Proc.CIGR V. International Conf. Argentina, Rosario 